\title{
The Determinant of Green Entrepreneurial Knowledge on SMEs in Indonesia
}

\author{
Iswanti, Amir Machmud, Eeng Ahman, Dita Maharani Suwardi \\ Universitas Pendidikan Indonesia \\ Email: iswanti@upi.edu
}

\begin{abstract}
This study aims at analyzing factors that influence green entrepreneurial knowledge on SMEs in West Java. The variables reviewed in this study were the role of entrepreneurship education, media, public figure, and government on green entrepreneurial knowledge. It used explanatory survey to collect data. The population in this study were 4.285 SMEs engaged in the culinary industry in Bandung. The sample retrieval technique employed was the Slovin formula which resulted on 240 respondents. Furthermore, the collected data was analyzed using Multiple Regression Analysis. The results show that the influential factors in increasing green entrepreneurial knowledge are entrepreneurship education, media, public figures, and government both partially and simultaneously. These findings implied that it is essential to improve green entrepreneurial knowledge; it takes the role of media, public figures, entrepreneurship education, and government.
\end{abstract}

Keywords: green entrepreneurial knowledge, media, government, SMEs

\section{INTRODUCTION}

Small and medium enterprises (SMEs) are among the leading driving forces in economic development (Bismala, 2014). The SMEs in the plays several pivotal roles for Indonesian economy, including a major player in economic activity, provider of employment, important sector in economic development and community empowerment source of innovation and creators of new markets (Tedjasuksmana, 2014). Therefore, it is crucial to grow SMEs to obtain labors and use local resources thus it could reduce poverty, equalize income distribution, and economic development (Sudayanto et al., 2011).

The number of SMEs in Indonesia tends to increase every year. The development is described in Table 1. From the table, it can be seen that the number of SMEs has showed an upward trend. The average increase was 2.3 percent. On the other hand, the number of industries from SMEs that increase each year impacts the environment. The relationship between Industrial sector development and Environmental Quality Index like an upside down $U$ shape which means that at the beginning of economic development in industrial and transportation sectors will be followed by an increase in income accompanied by environmental damage (Febriana et al., 2019). In line with this, there is a positive correlation between the pattern of $\mathrm{CO} 2$ carbon emission from the manufacturing industries and the Gross Domestic Product (GDP) in Indonesia (Rajagukguk, 2015). It is further revealed that economic growth is affected by $\mathrm{CO}^{2}$ emissions, and $\mathrm{CO}^{2}$ emissions are positively affected by economic growth in Indonesia. Economic growth and human activity offers negative impact to the environment (Rajagukguk, 2015). 
Table 1. The number of Indonesian SMEs

\begin{tabular}{llllll}
\hline Year & $\mathbf{2 0 1 4}$ & $\mathbf{2 0 1 5}$ & $\mathbf{2 0 1 6}$ & $\mathbf{2 0 1 7}$ & $\mathbf{2 0 1 8}$ \\
\hline $\begin{array}{l}\text { SMEs } \\
\begin{array}{l}\text { The increase } \\
\text { of SMEs (\%) }\end{array}\end{array}$ & 57.895 .721 & 59.262 .772 & 61.651 .177 & 62.922 .617 & 64.194 .057 \\
\hline
\end{tabular}

Source: The Ministry of Cooperatives and SMEs, 2020

The deteriorating quality of the environment should be taken into account by the community. The awareness should be established to implement the green concept, which offers an essential capacity in life, including in the economic sector (Siswanto et al., 2012). The phenomenon of environmental gradation sparked a new trend, specifically the Green Economy. Green Economy is a concept that prioritizes the balance between economic, social, and ecological values (Loiseau et al., 2016). UNEP (2011) has defined the green economy as an approach to improve "well-being social equity and reduced risks to the environment. The green economy is considered as low carbon, resource-efficient, and social responsible (UNEP, 2011). Green economic development efforts require the entrepreneur to continuously innovate and exploit all sorts of opportunities to create economic value, and green entrepreneurs are individuals who see environmental issues as an opportunity for business and undertake to innovate and take advantage of (Suyatna et al., 2018).

Green Entrepreneurship is an approach of entrepreneurship that pays attention to eco-friendly commitment. Green Entrepreneurship is far beyond what a conventional business might be performed but it comprises activities to protect and preserve the environment (Lotfi et al., 2018). Further, it aims at creating novel products and technologies to solve environmental problems (York \& Venkataraman, 2010). At the beginning, the term green entrepreneurship was a combination between entrepreneurship and environment (Lotfi et al., 2018). Then, it evolved into a new type of entrepreneurship with a commitment to establish businesses and preserve the environment. Green entrepreneurship seeks to integrate the environment and the social benefits of business to provide a competitive advantages (Lotfi et al., 2018).

Green entrepreneurial ideas can be disseminated by developing and using green knowledge through increased awareness among the population, especially among SMEs (Suyatna et al., 2018). Awareness is the amount of information stored in the mind of an individual that influences how customers view and analyze the choices available (Tan, 2011). Knowledge is divided conceptually into two elements: empirical knowledge and subjective knowledge. Objective information refers to the content and data about product types/problems/objects preserved in a person's mind. Subjective awareness, on the other hand, is the interpretation or estimation by an individual of what they understand and how much they believe about a product/problem/object. Green awareness is the capacity of an individual to understand and assess the effect of ecosystems on society (Tan, 2011). Green awareness includes the ability of an individual to identify different symbols, terms, and attitudes associated with environmental issues (Laroche \& Bergeron, 2016). Green Entrepreneurial Awareness (GEK) is a general understanding of the natural environment and business facts, concepts, and relationships (Fryxell \& Lo, 2003). 
The level of public awareness of the value of green entrepreneurship is currently considered to be inadequate. The number of SMEs implementing the green concept is smaller than that of entrepreneurs who have not adopted the green concept. (Sriyono, 2014). SME's entrepreneur employs the Green concept as pressure from external factors, not an awareness that arises internally (Handoko, 2012). The use of Styrofoam and plastic rife among vendors demonstrates a lack of green awareness in SMES entrepreneurs. (Muler, 2020). Inappropriate sewage treatment can also disrupt the environment (Zulfikar, 2019). Residual waste during manufacturing is discharged into landfills or seas to pollute the oceans and living things. During the production process, the chemical content could cause air pollution, thereby promoting global warming. (Leman et al., 2020).

Increased knowledge from SMEs about the green entrepreneurial concept is necessary for preserving the micro and global environment. Several factors support the Green Entrepreneurship Knowledge of SMEs in Indonesia, one of which is entrepreneurship education. Entrepreneurial education is a formally structured transfer of entrepreneurial competence, which refers to individuals' concept, skills, and mental awareness to start and grow a business venture (Greene et al., 2015). Entrepreneurial education can be defined as a deliberate treatment by an educator in student life to influence entrepreneurship's quality and skills to enable students to survive in the business world (Gamede \& Uleanya, 2017). Previous research shows that Entrepreneurial Education plays an essential role in shaping entrepreneurship's spirit (Lee et al., 2005). There is a difference between students who are given entrepreneurial courses and those who are not given entrepreneurship courses in comparative studies of entrepreneurial education between the USA and Korean students (Lee et al., 2005). In line with this, the educational process that runs at the University plays a role in supporting students' interest in green entrepreneurship into a green entrepreneurial behavior (Yi, 2020).

In the spread of public concern for the environment, the media seems to take a role. There are three media roles for the environment: campaigning, education, and promotional facilities (Pambudi et al., 2016). As a means of campaigning, media aims at raising awareness, informing, or changing campaign targets' behavior. The media, similar to education, provides the world with new information. As a method of promoting, the media persuade potential buyers to draw attention to products and services. The media plays a major role in shaping the perception of a person and in leading their thinking to a particular thing (McCombs and Shaw, 1972). The amount and type of media coverage of the climate, disasters and conflicts have converted many individual issues into national issues (Qader, 2011). The mass media affects psychological and ecological matters (Yu et al., 2017).

The rise in awareness of green entrepreneurship is not separated from the position of public figures. Public leaders are individuals in the community, valued by the community, have more understanding, lead the community, and appear to affect decision-making (Utami \& Khonitan, 2018). Public figures have leadership characteristics, integrity, and establishment, to accommodate commitment to the community (Weerawardena \& Mort, 2006). Public figures are formal and informal (Kusnadi \& Iskandar, 2017). A formal public figure is a person who has a structural 
position and is formally elected by the people (the Governor, Chief of a village). At the same time, informal public figures are recognized by society because they deserve to be the respected leaders and play a significant role in leading and supporting the community. As a formal public figure, the village's Chief plays a role in conveying information to the public about ecological hygiene (Adha, 2015). On the other hand, religion affects green products' consumption (Davari et al., 2017). Therefore, religious leaders can appeal to preserve the environment and improve green knowledge (Torabi \& Noori, 2019).

As a formal institution, government support plays an essential role in environmental entrepreneurship by creating regulatory pressures (Berrone et al., 2013). The government is responsible for providing adequate instruments for addressing uncertainties and risks related to access to financial resources (Silajdžić et al., 2015). The government can provide SMEs with the necessary support in overcoming significant barriers and encouraging investment in green markets. Regulatory reform, standards, and public procurement could strengthen the growing green market. Eco-friendly information and labeling campaigns are useful tools in promoting green businesses (Silajdžić et al., 2015).

This study focuses on culinary SMEs. Central Agency on Statistics (2018) shows that the creative economy business's highest subsector is the culinary industry which has 67.66 percent. West Java is among the five provinces in Indonesia that account for the highest GDP in the creative industries category, 11.81\% (Badan Pusat Statistik, 2018). West Java is also the highest export contributor in the creative industry category, 31.96 percent. Thus, this research is essential to be performed mostly in areas that dominate the creative industry business.

\section{METHODS}

The research employed explanatory survey. Data collection techniques were carried out using a questionnaire distributed to the respondents. This research was conducted in Bandung with the topic of culinary entrepreneurs to 4,285 entrepreneurs. The Slovin's formula was used as a sampling technique to obtain a sample of 240 respondents. The sampling method used purposive sampling, where the sample has specific criteria. It took culinary entrepreneurs with two or more employees and have started a culinary business for at least two years. Data measurements were performed using five Likert scales.

Most respondents were male (56\%) and female (44\%). This condition indicated that men still dominated Indonesia's culinary sector. However, there was a tendency for the increasing number of women entrepreneurs. Most respondents were aged between $30-51$ years (63\%) while the rest of them were under 30 years $(20 \%)$ and above 50 years (17\%). This condition showed that entrepreneurs are generally still productive. Most of the respondents were high school graduates (55\%), bachelor graduates (20\%), and the rest were junior high school and elementary school graduates. This condition showed that the entrepreneurs were mostly well educated. 
The independent variables (X) presumed affecting green knowledge are entrepreneurship education's role, media role, the role of public figures, and the government role. The dependent variable (Y) in this study is Green Entrepreneurial Knowledge in culinary SMEs. Green Entrepreneur Knowledge (GEK) is described in three dimensions: clean growth, socially aware business, and environmentally safe business (Dixon \& Clifford, 2007). The conceptual framework in this study is illustrated in Figure 1.

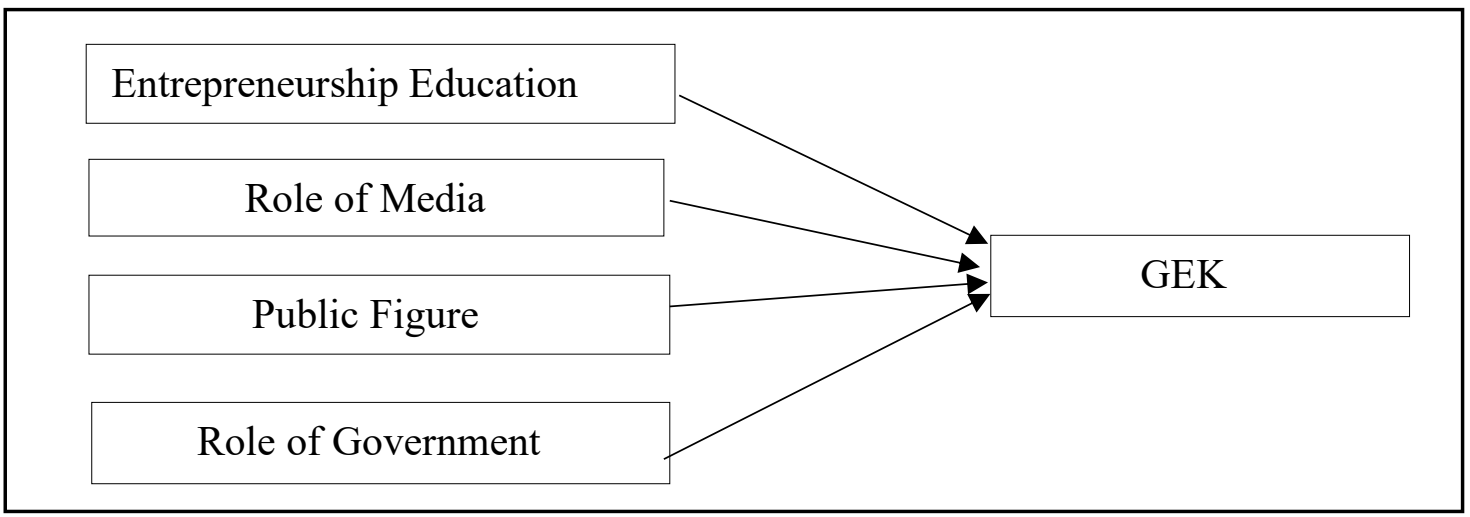

Figure 1. Research variable

To test the hypothesis, it employed Multiple Linear Regression as follows:

$$
\mathrm{Y}=\mathrm{a}+\mathrm{b}_{1} \mathrm{x}_{1}+\mathrm{b}_{2} \mathrm{X}_{2}+\mathrm{b}_{3} \mathrm{X}_{3}+\mathrm{b}_{4} \mathrm{X}_{4}+\mathrm{e}
$$

Annotation:

$\mathrm{Y}=$ Green Entrepreneurial Knowledge

$\mathrm{X} 1=$ Entrepreneurship Education

$\mathrm{X} 2=$ Media

$\mathrm{X} 3=$ Public figures

$\mathrm{X} 4=$ Government

a $\quad=$ Constant

$\mathrm{b} \quad=$ Regression coefficient

The hypothesis of this research is formulated as follows:

H1: Entrepreneurship Education influence Green Entrepreneur Knowledge

H2: Media influence on Green Entrepreneur Knowledge

H3: Public figures influence on Green Entrepreneur Knowledge

H4: Government influence on Green Entrepreneur Knowledge

\section{RESULTS \& DISCUSSION}

\section{Validity and Reliability Test}

Before interpreting the results of the analysis, the instrument quality test was carried out through validity and reliability tests. Validity tests were performed by using Pearson Product Moment. Based on the Pearson product moment, all indicators were valid and utilizable, and this was indicated by a significant value of $\mathrm{p}<0.05$. A clearer data presentation can be seen in Table 2 . 
The instrument reliability test is performed by observing the reliability coefficient's value based on Cronbach's Alpha value. Based on the reliability test, as shown in Table 3, it can be noted that Cronbach's Alpha value $>0.70$, thus the conclusion is that all variables could be used for further analysis.

Table 2. Validity Test

\begin{tabular}{llccc}
\hline No & Item & P Value & Significant & Conclusion \\
\hline 1 & EE_1 & 0.001 & 0.05 & Valid \\
2 & EE_2 & 0.001 & 0.05 & Valid \\
3 & EE_3 & 0.001 & 0.05 & Valid \\
4 & EE_4 & 0.001 & 0.05 & Valid \\
5 & Media_1 & 0.001 & 0.05 & Valid \\
6 & Media_2 & 0.001 & 0.05 & Valid \\
7 & Media_3 & 0.001 & 0.05 & Valid \\
8 & Public Figures_1 & 0.001 & 0.05 & Valid \\
9 & Public Figures_2 & 0.001 & 0.05 & Valid \\
10 & Public Figures_3 & 0.001 & 0.05 & Valid \\
11 & Public Figures_4 & 0.001 & 0.05 & Valid \\
12 & Government_1 & 0.001 & 0.05 & Valid \\
13 & Government_2 & 0.001 & 0.05 & Valid \\
14 & Government_3 & 0.001 & 0.05 & Valid \\
15 & Government44 & 0.001 & 0.05 & Valid \\
16 & Green Knowledge_1 & 0.001 & 0.05 & Valid \\
17 & Green Knowledge_2 & 0.001 & 0.05 & Valid \\
18 & Green Knowledge_3 & 0.001 & 0.05 & Valid \\
\hline
\end{tabular}

Table 3. Reliability Test

\begin{tabular}{ccccc}
\hline No & Variable & $\begin{array}{c}\text { Cronbach's } \\
\text { Alpha }\end{array}$ & $\begin{array}{c}\text { Minimum Cronbach } \\
\text { Alpha }\end{array}$ & Conclusion \\
\hline 1 & EE & 0.936 & 0.70 & Reliable \\
2 & Media & 0.955 & 0.70 & Reliable \\
3 & Public Figures & 0.955 & 0.70 & Reliable \\
4 & Government & 0.931 & 0.70 & Reliable \\
5 & Green Knowledge & 0.809 & 0.70 & Reliable \\
\hline
\end{tabular}

\section{Hypothesis Test}

Table 4 shows hypothetical test results that entrepreneur education (X1), media (X2), public figures (X3), and government (X4) have a positive effect on green entrepreneurship knowledge $(Y)$ in culinary SMEs entrepreneurs.

Table 4. Partial Test

\begin{tabular}{clccccc}
\hline Model & \multicolumn{2}{c}{$\begin{array}{c}\text { Unstandardized } \\
\text { Coefficients }\end{array}$} & $\begin{array}{c}\text { Standardized } \\
\text { Coefficients }\end{array}$ & t & Sig. \\
\hline 1 & (Constant) & -1.605 & 4.804 & .376 & -.334 & .740 \\
& EE & .364 & .100 & .228 & 3.650 & .001 \\
& Media & .163 & .072 & .290 & 2.261 & .030 \\
& Public Figure & .314 & .103 &. & 3.043 & .004 \\
& Government & .215 & .086 & & 2.495 & .017 \\
\hline
\end{tabular}


Based on Table 4, hypothetical test results are explained as follows;

1. Entrepreneurship education has a significant effect on green entrepreneurial knowledge with a significance value of $0.001<0.05$, H1 was accepted

2. The media has a significant influence on green entrepreneurial knowledge e with a significance value of $0.030<0.05, \mathrm{H} 2$ was accepted

3. Public figures have a substantial effect on green entrepreneurial knowledge with a significance value of $0.004<0.05$, H3 was accepted

4. The government has a substantial influence on green entrepreneurial knowledge with a significance value of $0.015<0.05$, H4 was accepted

$\mathrm{R}$ Square test was used to test how much independent variables (the role of education, media, public figures, and government) influence green entrepreneurial knowledge variables. Based on the R Square test in Table 5, it can be known that the $\mathrm{R}$ square value 0.829 means green entrepreneurial knowledge of 82.9 percent was influenced by the role of entrepreneur education, media, public figures, and government, and other variables.

Table 5. Simultaneous Determination Coefficient

\begin{tabular}{ccccc}
\hline Model & $\mathbf{R}$ & R Square & $\begin{array}{c}\text { Adjusted R } \\
\text { Square }\end{array}$ & $\begin{array}{c}\text { Std. Error of } \\
\text { the Estimate }\end{array}$ \\
\hline 1 & $.920^{\mathrm{a}}$ & .846 & .829 & 2.58939 \\
\hline
\end{tabular}

Green knowledge focuses on inputs, processes, and outputs that pay attention to culinary microentrepreneurs' environmental aspects. The study results based on Adjusted $\mathrm{R}$ Square values show that the role of entrepreneur education, media roles, public figures' role, and government role were influenced by 82.9 percent towards green entrepreneurship knowledge. A complete understanding of green entrepreneurship needs to be performed due to dwindling natural resources and environmental problems. Environmental opportunities have steered an entrepreneurial approach to sustainable development, where entrepreneurs can create a sustainable future.

In order to generate new outputs, green entrepreneurship emphasizes the transformation of the idea of production, activity, and innovation, using technology to promote sustainable growth (Lotfi et al., 2018). In business practices, knowledge of green entrepreneurship is applied, such as reducing environmental degradation; striking a balance between growing company income, considering the environment and taking into account creativity and new green business methods; prioritizing the development of goods and services for profitability and green trade; providing prospects for professionalism;

This study shows that entrepreneurship education has a positive effect on the green entrepreneurial perception of SMEs shown in the results of the t test with a significance of $<0.05$. A community of people's awareness, skills, and habits are typically passed down through teaching, training, or study from one generation to the next (Dewey, 1944), therefore education might instill principles of environmental care and promotes appropriate behaviors (Damerell et al., 2013). It 
is expected that entrepreneurial education will provide inspiration, experience, and essential skills for the future.

The goal of entrepreneurship education is to expose students to job prospects and increase entrepreneurial awareness, provide a solid knowledge base about entrepreneurship, improve students' entrepreneurial skills and abilities through classroom learning and other activities. There are three primary educational support areas for Green Entrepreneur Knowledge (GEK): (1) strategy, organizational structure, entrepreneurial space, capital supporting GEK. (2) entrepreneurial policies that support GEK, and (3) green entrepreneur culture in school. The entrepreneurship education stimulates and encourages students' green development perceptions (Yi, 2020).

Integrating green concepts in entrepreneurship education is indeed necessary. The education system promotes a responsibility for thinking and creating alternatives to new ideas. The role of education to enhance green entrepreneurship knowledge are; creating public awareness to achieve sustainable development, making a green education curriculum delivers knowledge and skills required in the industry, applying green concepts in every process in education. The program will lead to different thoughts among students and assist them in all kinds of social interactions. Students who graduate from such a system will create environmentally friendly business opportunities.

T-test results with a significance of $<0.05$ showed that the media played a role to improve SMEs towards green entrepreneurship knowledge. Through the influence media, insights on green knowledge are conveyed to the broader community to create and provide new knowledge. The communication pattern that needs to be used in the communication pattern is mass media. The media directs people's perception and actions towards green entrepreneurship, which values the environment as a new culture. The media serves as a mean of campaign and education to promote green entrepreneurship. As a campaigner, the media encourages entrepreneurs to join in the company's green movement. The quality of the knowledge is not only a green discourse notification, but also an interpretation of green entrepreneurship. Awareness of green entrepreneurship is best articulated in languages that are easy to understand and backed by evidence. In education, the media needs to clarify the causes and effects of environmental degradation and how alternatives are presented through the idea of green entrepreneurship.

Media functions and offers data in the form of commercials, encouraging customers to purchase and still remember the advertised product. As a marketing, the media offers details about goods belonging to the green group, so that the public understands and assumes that the product is indeed the product of a green entrepreneur. Pro-environmental behavior and behaviors are positively influenced by the use of news media (Holbert et al., 2003). The media is playing with the repetition of advertisements, continuity, and corroborating facts to alter public sentiment in the long run. If the media attention continues to increase highlighting various environmental issues, it can form a higher ecological concern among the community (Trivedi et al., 2018).

Increasing in green awareness are not separated from the support of public figures. The results of the test $t<0.05$ demonstrate this. Formal and informal 
community leaders serve as mentors, coordinators, motivators and examples to raise awareness of green knowledge among the general public (Utami \& Khonitan, 2018).

Counselors are charged with having awareness of the technicalities of green entrepreneurship and how it is promoted. The coordinators give advice to SME representatives to implement the green business concept. Motivators inspire green entrepreneurship programs to be carried out. An example of the introduction of green entrepreneurship activities is an example of this. Informal public figures, such as religious leaders, play a crucial role in mobilizing their followers to eat green goods (Davari et al., 2017). Public figures are potential agents of social change (Potter \& Halliday, 1990). Some environmental advocates, such as ecological groups, environmental practitioners, and individuals, contribute to developing green awareness (Jamison, 2003).

The government has a role in green knowledge-based which was indicated by the t-tests with a significance of $<0.05$. The government act as a policymaker who encourages people to be pro-environmental. The government is responsible for environmental efficiency, regulations, policy proposals and taxes (Gluch \& Stenberg, 2006). Activities that the government should carry out to encourage green entrepreneurship are: policy intervention, intervention in current entrepreneurial growth policies, proposals to optimize the use of entrepreneurial development funds, distribution of green entrepreneurial knowledge (Silajdžić et al., 2015). Through its policies and interventions, the government supports the development of innovation in entrepreneurship by facilitating new businesses and residual concentration of claims (Michael \& Pearce, 2009).

Financial and technological assistance from the government are proven to increase the acquisition of patents and new business SMEs at the regional level (Doh \& Kim, 2014). The government distributes loans and grants through banks to encourage SMEs' development by financing various private business activities, supporting incubators and business zones (Silajdžić et al., 2015). Previous research has shown that the role of government has a positive effect on green entrepreneurship; the incentive policies influence new companies' formation (Sunny \& Shu, 2019), political support has a positive impact on diversifying in green technology (Santoalha \& Boschma, 2020), and environmentally friendly local government policies and environmental awareness from local communities positively impact clean technology entry in a region (Giudici et al., 2019).

\section{CONCLUSION}

This research concludes that the increase in green knowledge among SMEs is influenced by several factors, including the role of entrepreneur education, the role of the media, the role of public figures and the government. Entrepreneurship education direct students to create, discover, and act on opportunities that promote profitable value. Media motivates people to adhere to pro-environmental behavior. Public figures are potential agents of change in society. The government supports the development of innovation in entrepreneurship by providing recycling facilities, dissemination of green entrepreneurial information, distributes 
loans and grants through banks to encourage SMEs' development. This study's limitations are related to the factors that influence green entrepreneurship knowledge, although there are still many factors that can affect it both internally and externally. Besides that, this study's limitations are related to limited sampling so that the results of this study cannot be generalized.

\section{ACKNOWLEDGEMENTS}

The authors would like to send our greatest gratitude to Indonesia Endowment Fund for Education (LPDP) which has provided us financial support to conduct this research.

\section{REFERENCES}

Adha, R. (2015). Peran komunikasi interpersonal lurah dalam meningkatkan partisipasi masyarakat pendatang pada program hijau bersih sehat (Hbs) di Kelurahaan Sidomulyo Kecamatan Samarinda Ilir Kota Samarinda. E-Journal Ilkom Fisip, 3(1), 398-415.

Badan Pusat Statistik. (2018). Data statistik dan hasil survey ekonomi kreatif (Vol. 7, Issue 9).

Berrone, P., Fosfuri, A., Gelabert, L., \& Gomez-Mejia, L. R. (2013). Necessity as the mother of "green" inventions: Institutional pressures and environmental innovations. Strategic Management Journal, 34(8), 891-909. https://doi.org/10.1002/smj.2041

Bismala, L. (2014). Analisis Strategi pemasaran pada UMKM di sumatera utara untuk meningkatkan daya saing UMKM. Jurnal Pembangunan Perkotaan.

Damerell, P., Howe, C., \& Milner-Gulland, E. J. (2013). Child-orientated environmental education influences adult knowledge and household behaviour. Environmental Research Letters, 8(1), 015016 https://doi.org/10.1088/1748-9326/8/1/015016

Davari, A., Iyer, P., \& Strutton, D. (2017). Investigating moral links between religiosity, altruism, and green consumption. Journal of Nonprofit and Public Sector Marketing, 29(4), 385-414. https://doi.org/10.1080/10495142.2017.1326338

Doh, S., \& Kim, B. (2014). Government support for SME innovations in the regional industries: The case of government financial support program in South Korea. Research Policy, 43(9), 1557-1569. https://doi.org/10.1016/j.respol.2014.05.001

Febriana, S., \& Diartho, H. I. (2019). Hubungan pembangunan ekonomi terhadap kualitas lingkungan hidup di provinsi Jawa Timur. Jurnal Dinamika Ekonomi Pembangunan, 2(2), 1-13.

Fryxell, G. E., \& Lo, C. W. H. (2003). The influence of environmental knowledge and values on managerial behaviours on behalf of the environment : An empirical examination of managers in China. Journal of Business Ethics, 45-69. 
Gamede, B. T., \& Uleanya, C. (2017). The role of entrepreneurship education in secondary schools at further education and training phase. Academy of Entrepreneurship Journal, 23(2), 1-12.

Giudici, G., Guerini, M., \& Rossi-Lamastra, C. (2019). The creation of cleantech startups at the local level: the role of knowledge availability and environmental awareness. Small Business Economics, 52(4), 815-830. https://doi.org/10.1007/s11187-017-9936-9

Gluch, P., \& Stenberg, A. C. (2006). How do trade media influence green building practice? Building Research and Information, 34(2), 104-117. https://doi.org/10.1080/09613210500491613

Greene, P. G., Brush, C. G., Eisenman, E. J., Neck, H., \& Perkins, S. (2015). Entrepreneurship education: a global consideration from practice to policy around the world with contributions from: the finnish lifelong learning foundation. 112. www.XueTangX.com

Holbert, R. L., Kwak, N., \& Shah, D. V. (2003). Environmental concern, patterns of television viewing, and pro-environmental behaviors: integrating models of media consumption and effects. Journal of Broadcasting \& Electronic Media, 47(2), 177-196. https://doi.org/10.1207/s15506878jobem4702_2

Jamison, A. (2003). The making of green knowledge: The contribution from activism. Futures, 35(7), 703-716. https://doi.org/10.1016/S00163287(03)00023-5

Kusnadi, E., \& Iskandar, D. (2017). Peranan tokoh masyarakat dalam membangun partisipasi kewargaan pemuda karang taruna. Prosiding Konferensi Nasional Kewarganegaraan III, November, 358-363.

Laroche, M., \& Bergeron, J. (2016). Targeting consumers who are willing to pay more for environmentally friendly products journal of consumer marketing article information : July. https://doi.org/10.1108/EUM0000000006155

Lee, S. M., Chang, D., \& Lim, S. (2005). Impact of entrepreneurship education: a comparative study of the U.S. and Korea. The International Entrepreneurship and Management Journal, 1(1), 27-43. https://doi.org/10.1007/s11365-0056674-2

Leman, F. M., \& Soelityowati, J. P. (2020). Dampak Fast fashion terhadap lingkungan. Seminar nasional envisi 2020: Industri kreatif. http://www.fastfashion-dieausstellung.de/de/

Loiseau, E., Saikku, L., Antikainen, R., Droste, N., Hansjürgens, B., Pitkänen, K., Leskinen, P., Kuikman, P., \& Thomsen, M. (2016). Green economy and related concepts: An overview. Journal of Cleaner Production, 139, 361-371. https://doi.org/10.1016/j.jclepro.2016.08.024

Lotfi, M., Yousefi, A., \& Jafari, S. (2018). The effect of emerging green market on green entrepreneurship and sustainable development in knowledge-based companies. Sustainability, 10(7). https://doi.org/10.3390/su10072308

Michael, S. C., \& Pearce, J. A. (2009). The need for innovation as a rationale for government involvement in entrepreneurship. Entrepreneurship and Regional Development, 21(3), 285-302. https://doi.org/10.1080/08985620802279999

Muler, Y. \& R. (2020). Pemanfaatan limbah plastik menjadi produksi industri kreatif. Jurnal Abdimas Mandiri, 4(1), 1-10. 
Pambudi, T. S. (2016). Peran media dalam menginformasikan wacana green design kepada masyarakat. Idealog: Ide dan Dialog Desain Indonesia, 1(1), 37-46.

Potter, J., \& Halliday, Q. (1990). Community leaders. A device for warranting versions of crowd events. Journal of Pragmatics, 14(6), 905-921. https://doi.org/10.1016/0378-2166(90)90046-G

Qader, I. K. \& Y. Z. (2011). Investigating the influence of safety and health concerns and self-efficacy on lecturer's environmental attitudes towards electronic green products. Interdisciplinary Journal of Contemporary Research in Business, 3(2), 366-381.

Rajagukguk, W. (2015). Hubungan degradasi lingkungan dan pertumbuhan ekonomi: kasus Indonesia. Proceeding of the Dinamika Dan Peran Ilmu Manajemen Untuk Menghadappi AEC, November 2015. https://doi.org/10.13140/RG.2.2.17987.91680

Santoalha, A., \& Boschma, R. (2020). Diversifying in green technologies in European regions: does political support matter? Diversifying in green technologies in European regions: does political support matter? Regional Studies, O(0), 1-14. https://doi.org/10.1080/00343404.2020.1744122

Silajdžić, I., Kurtagić, S. M., \& Vučijak, B. (2015). Green entrepreneurship in transition economies: A case study of Bosnia and Herzegovina. Journal of Cleaner Production, 88, 376-384. https://doi.org/10.1016/j.jclepro.2014.07.004

Siswanto, B., Adrie, D., \& Wacana, K. K. (2012). Pendekatan Kelembagaan dalam pengembangan model perekonomian hijau. Ilmiah Manajemen Bisnis, 99-106.

Sriyono. (2014). Implementation of Green Economy on The Development of SMEs in Sidoarjo District. The Third International Conference On Entrepreneurship and Business Management (ICEBM), November 2014.

Sudayanto., Ragimun., \& Rahma, R. (2011). Starategi pemberdayaan UMKM menghadapi pasar bebas ASEAN. Universitas Negeri Jember, 1(UMKM $\begin{array}{llll}\text { menghadapi pasar bebas } & \text { ASEAN), }\end{array}$ http://jurnal.unpad.ac.id/sosiohumaniora/article/view/12249/6227

Sunny, S. A., \& Shu, C. (2019). Investments, incentives, and innovation: geographical clustering dynamics as drivers of sustainable entrepreneurship. Small Business Economics, 52(4), 905-927. https://doi.org/10.1007/s11187017-9941-z

Suyatna, H., Santosa, A., Nayono, I. S., \& Wibowo, I. A. (2018). Model inkubator kewirausahaan hijau: Studi kasus di desa Nglanggeran, Kabupaten Gunungkidul DIY. January.

Tan, B. C. (2011). The roles of knowledge, threat, and PCE on green purchase behaviour. International Journal of Business and Management, 6(12), 14-27. https://doi.org/10.5539/ijbm.v6n12p14

Tedjasuksmana, B. (2014). Potret Umkm Indonesia menghadapi masyarakat ekonomi Asean 2015. The 7th NCFB and Doctoral Colloquium 2014 Towards a New Indonesia Business Architecture Business And Economic Transformation Towards AEC 2015, 189-202.

Torabi, M., \& Noori, S. M. (2019). Religious leaders and the environmental crisis using knowledge and social influence to counteract climate change. Ecumenical Review, 71(3), 344-355. https://doi.org/10.1111/erev.12434 
Trivedi, R. H., Patel, J. D., \& Acharya, N. (2018). Causality analysis of media influence on environmental attitude, intention and behaviors leading to green purchasing. Journal of Cleaner Production, 196, 11-22. https://doi.org/10.1016/j.jclepro.2018.06.024

UNEP. (2011). Pathways to sustainable development and poverty eradication - A Synthesis for Policy Makers. Towards a GREEN Economy, 52.

Utami, B. N., \& Khonitan, D. (2018). Peran tokoh masyarakat dalam menumbuhkan jiwa social enterprenerurship masyarakat berbasis pertanian di Desa Bukit Langkap Kabupaten Lingga. Seminar Nasional Politeknik Pembangunan Pertanian Malang, 1.

Weerawardena, J., \& Sullivan Mort, G. (2006). Investigating social entrepreneurship: A multidimensional model. Journal of World Business, 41(1), 21-35. https://doi.org/10.1016/j.jwb.2005.09.001

Yi, G. (2020). From green entrepreneurial intentions to green entrepreneurial behaviors: the role of university entrepreneurial support and external institutional support. International Entrepreneurship and Management Journal, 2. https://doi.org/10.1007/s11365-020-00649-y

York, J. G., \& Venkataraman, S. (2010). The entrepreneur-environment nexus: Uncertainty, innovation, and allocation. Journal of Business Venturing, 25(5), 449-463. https://doi.org/10.1016/j.jbusvent.2009.07.007

Yu, T. Y., Yu, T. K., \& Chao, C. M. (2017). Understanding Taiwanese undergraduate students' pro-environmental behavioral intention towards green products in the fight against climate change. Journal of Cleaner Production, 161, 390-402. https://doi.org/10.1016/j.jclepro.2017.05.115

Zulfikar, R. \& P. A. M. (2019). The Level of environment knowledge, perception , and behavior of South Kalimantan MSME in implementing the green economy. Prosiding Seminar Nasional Lingkungan Lahan Basah, 4(April), 459-464. 